EUROPA REGIONUM TOM XXVIII ROK 2016

DOI: $10.18276 /$ er.2016.28-04

\author{
HUBERT BRONK, AGNIESZKA KWARCIŃSKA \\ Uniwersytet Szczeciński
}

\title{
Teoretyczna równowaga i praktyczna nierównowaga ekonomiczna
}

\section{Wprowadzenie}

$\mathrm{Z}$ naczenie słów teoria i praktyka pochodzi z greki i łaciny. Teoria (theoria gr., łac.) oznacza: obserwacja, oglądanie, pogląd oparty na faktach obserwowanych, natomiast praktyka (praktikos - gr.) to tyle co - działać, aktywny ${ }^{1}$. Teoria naukowa to całość logicznie spoistych uogólnień, wywnioskowanych na podstawie ustalonych faktów naukowych i powiązanych z dotychczasowym stanem nauki. Ma na celu wyjaśnienie przyczyny lub układu przyczyn, warunków, okoliczności powstawania i określonego przebiegu danego zjawiska. Z kolei praktyka - to świadoma i celowa działalność ludzka. Utożsamiana jest z materialnymi działaniami człowieka, a w szczególności $\mathrm{z}$ pracą, czyli z życiową działalnością człowieka, która pozwala zaspokajać jego potrzeby, zwłaszcza biologiczne. W innym przypadku ujmuje się praktykę jako całość materialnej działalności ludzkich społeczności, a indywidualne działania praktyczne traktuje się jako składniki owej całości. Teoria i praktyka wydają się zatem być faktami oddzielnymi. Między nimi istnieje jednak relacja wskazująca na punkty wspólne i konieczność wzajemnego dopełniania się. Teoria i praktyka to jak dwie strony medalu, a mianowicie: bez teorii (wiedzy) praktyka może prowadzić donikąd, bez praktyki teoria pozostaje czysto intelektualną zabawą.

Ekonomia jest dyscypliną naukową tzw. stosowaną, co oznacza, że z racji jej przedmiotu oraz roli jaką spełnia w życiu człowieka, oprócz tworzenia no-

${ }^{1}$ Stownik języka polskiego, PWN, Warszawa 1979, t. II. s. 908; t. III s. 494; Stownik wyrazów obcych, PWN Warszawa 1995, s. 890 i s. 1102. 
wych teorii powinna poszukiwać implikacji praktycznych. Zatem między teorią i praktyką ekonomiczną musi występować sprzężenie zwrotne, chociaż niekiedy między teorią i praktyką ,rozwarcie nożyc” może być tak duże, że brakuje między nimi jakiejkolwiek relacji (przykładem są modele ekonometryczne rozwoju polskiej gospodarki na lata 80 . XX w., które zupełnie rozmijały się z rzeczywistymi zmianami rozwoju gospodarczego). Praktycy powinni być otwarci na nowe teorie ekonomiczne, a w konsekwencji także na pogłębianie swojej wiedzy teoretycznej. Z drugiej natomiast strony teoretycy ekonomii muszą być bacznymi obserwatorami polityki gospodarczej, śledzić systematycznie aktualną sytuację gospodarczą, a ponadto starać się zabiegać o stały kontakt z praktyką gospodarcza. $\mathrm{O}$ ile istnieje dysonans między teorią i praktyką gospodarczą, to jest to symptom, że teoretyk jest oderwany od życia gospodarczego, od praktyki, albo praktyk z raz zdobytej wiedzy uczynił dogmat nie przyjmując przemian zachodzących w teorii ekonomii.

Prawie wszyscy, a przynajmniej znacząca część praktyków gospodarczych w swoich działaniach (np. przy podejmowaniu decyzji) niechętnie odnoszą się do teorii, nowych modeli czy metod działania, nawet wówczas, kiedy są one gruntownie zbadane i zweryfikowane. W takich przypadkach zwykle podkreślają i odwołują się do własnych doświadczeń i obserwacji, chociaż sprawiają one im trudności w zarządzaniu podmiotami gospodarczymi. Wówczas teoria musi wskazać, jak należy zdobywać nową wiedzę i zweryfikować ją w praktyce za pomocą prób i obserwacji. Praktyka dała początek teorii, z której następnie czerpie się w dzisiejszej praktyce. Innymi słowy bez praktyki gospodarczej nie ma dobrej teorii i odwrotnie bez teorii nie ma dobrej praktyki gospodarczej.

Uwzględniając rozważania na temat znaczenia teorii i praktyki w ekonomii i odnosząc się w tym zakresie do zagadnień związanych z równowagą ekonomiczną, sformułować można stwierdzenie, że teoretycznie opisany w postaci modelu równowagi ekonomicznej stan nie stanowi reguły w praktyce gospodarczej. Jest ujmowany jako stan bardzo trudny do osiągnięcia, a jeszcze trudniejszy do utrzymania, w którym dany podmiot albo się znajduje, albo do którego zmierza. Zatem z punktu widzenia teorii stan taki istnieje, jest możliwy do zapisania, jednak w praktyce gospodarczej regułą jest raczej występowanie nierównowagi ekonomicznej. Celem artykułu jest zarówno zaprezentowanie wiedzy na temat wybranych teorii ekonomicznych związanych z istnieniem równowagi ekonomicznej jak również podkreślenie znaczenia i konieczności rozszerzania rozważań teoretycznych prowadzonych w ramach analizowanych stanów nierównowagi. 


\section{Równowaga ekonomiczna - ujęcie historyczne}

Za pierwotne przemyślenia na temat równowagi uznawane są te, które zapisał Adam Smith w swoim dziele pod tytułem „Badania nad naturą i przyczynami bogactwa narodów". Jego rozważania, nawiązujące do równowagi ekonomicznej, ujęte zostały przy okazji refleksji na temat wartości. Wyróżnił on wówczas kategorię ceny naturalnej, kształtowanej w długim czasie, która określana jest przez nakłady po podażowej stronie rynku ${ }^{2}$ oraz ceny rynkowe kształtowane w krótkim czasie poprzez działanie sił współzawodnictwa popytu i podaży. W sytuacji gdy popyt jest większy od podaży, cena rynkowa jest ponad ceną naturalną, zwiększa się wówczas dochód z czynników produkcji, a to przyciąga dodatkowe czynniki do danej gałęzi produkcji i zwiększa podaż towaru. Większa podaż obniża cenę rynkową do poziomu ceny naturalnej. ${ }^{3}$. W ten sposób ceny wszystkich towarów wahają się wokółceny naturalnej. Bywa, że na niektóre towary ceny rynkowe są niższe od ceny naturalnej, a na inne wyższe. Istotnym jest, że w całej gospodarce różnice się znoszą i występuje wówczas równowaga na rynku ${ }^{4}$.

Kolejnym ekonomistą w historii myśli ekonomicznej, który podejmował zagadnienia związane z równowagą był m.in. autor „Traktatu o ekonomii politycznej” - Jean-Baptiste Say, który sformułował prawo rynków. Zauważył, że produkowanie i dostarczenie produktów na rynek związane jest z koniecznością zaangażowania określonych czynników produkcji - ziemi, kapitału i pracy, które są odpowiednio wynagradzane. Wynagrodzenia te stanowią dochody, które w całości przeznaczane są na zakup wyprodukowanych towarów. Innymi słowy wytworzona i dostarczona na rynek oferta towarowa - podaż, tworzy zapotrzebowanie na siebie samą - popyt, w równej wielkości ${ }^{5}$. Tym samym stwierdzić można, że o ile w skali mikroekonomicznej czyli w odniesieniu do rynków konkretnych towarów możliwe byłoby występowanie nierównowagi, to w skali makroekonomicznej czyli w ujęciu gospodarki jako całości będzie miała miejsce równowaga. Nadprodukcja ogólna w sensie w skali całej gospodarki nie jest możliwa ${ }^{6}$.

${ }^{2}$ M. Blaug, Teoria ekonomii. Ujęcie retrospektywne. Wydawnictwo Naukowe PWN, Warszawa 2000 , s. 60

3 Stownik historii myśli ekonomicznej, red. E. Kundera, Oficyna Ekonomiczna, Kraków 2004, s. 187.

${ }^{4}$ Ibidem, s. 187.

${ }^{5}$ R. Bartkowiak, Historia myśli ekonomicznej, Polskie Wydawnictwo Ekonomiczne, Warszawa 2003, s. 43.

${ }^{6}$ M. Blaug, Teoria ekonomii..., op. cit., s. 161. 
Istotny wkład $\mathrm{w}$ rozważania na temat równowagi wniósł także przedstawiciel szkoły lozańskiej Leon Walras. Sformułował teorię równowagi ogólnej zapisanej jako „system zależności funkcjonalnych (równań), wyrażający taki stan gospodarki wymiennej, kiedy wszystkie gałęzie są jednocześnie zrównoważone wewnętrznie oraz znajdują się w równowadze między sobą"7. Poddał analizie szczególny typ gospodarki rynkowej określany jako model konkurencji doskonałej ${ }^{8}$. Cechą takiego modelu jest przede wszystkim występowanie bardzo wielu kupujących i sprzedających, którzy nie mają wpływu na kształtowanie się cen. Zarówno kupujący jak i sprzedający przyjmują cenę rynkową, kształtowaną przez siły popytu i podaży, są zatem cenobiorcami. Co jest jeszcze istotnym, obok struktury rynkowej Leon Walras analizował strukturę podmiotową gospodarki, którą tworzą gospodarstwa domowe i przedsiębiorstwa ${ }^{9}$. Schemat funkcjonowania tych dwóch sektorów został przedstawiony na rys. 1.

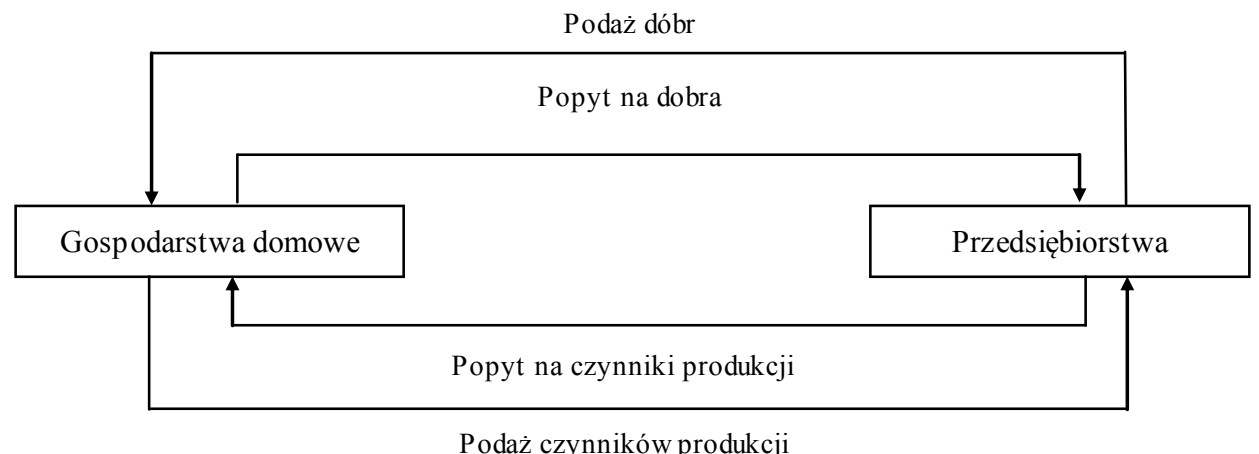

Rysunek 1. Funkcjonowanie dwóch sektorów gospodarki

Źródło: opracowanie własne na podstawie: Landreth i Colander, Historia myśli ekonomicznej, Wydawnictwo Naukowe PWN, 2005, s. 294.

7 J. Górski, W. Sierpiński, Historia powszechnej myśli ekonomicznej (1870-1950). Państwowe Wydawnictwo Naukowe, Warszawa 1987, s. 90. Warunki stanu ogólnej równowagi ekonomicznej ekonomia lozańska sformułowała następująco: 1. „Każdy konsument zmaksymalizował swój dochód płynący ze sprzedaży usług określonego czynnika produkcji (pracy, kapitału, ziemi) oraz zmaksymalizował zadowolenie osiagane $\mathrm{z}$ tego dochodu. 2. Każdy przedsiębiorca zastosował taką kombinację czynników wytwórczych, że osiąga maksymalny efekt produkcyjny przy minimalnym koszcie. 3. Na wszystkich rynkach dóbr konsumpcyjnych i kapitałowych ukształtowały się jednolite ceny równoważące podaż i popyt. 4. Na wszystkich rynkach czynników produkcji ukształtowały się jednolite ceny równoważące ich podaż z popy tem. 5. Nastąpiło wzajemne dostosowanie się kosztów (ceny czynników wytwórczych i dóbr kapitałowych) oraz cen gotowych wy robów." ibidem, s. 90.

${ }^{8}$ R. Bartkowiak, Historia myśli ekonomicznej... op. cit., s. 108.

${ }^{9}$ Ibidem, s. 108. 
Jak wynika $\mathrm{z}$ rys. 1 dwa główne podmioty rynkowe gospodarstwa domowe i przedsiębiorstwa spotykają się na rynku dóbr (towarów) i na rynku pracy. Każdy $\mathrm{z}$ nich występuje po stronie popytowej i podażowej, ale na różnych rynkach. Za pośrednictwem rynków, $\mathrm{z}$ jednej strony rynku dóbr (towarów) z drugiej strony rynków czynników produkcji, zarówno gospodarstwa domowe jak i przedsiębiorstwa realizują swoje cele. Gospodarstwa domowe dążą do realizacji możliwie największej konsumpcji i aby to osiągać potrzebują źródeł finansowania czyli dochodu (placy). Ich dochody pochodzą z angażowania czynnika wytwórczego jakim jest praca. Zatem aby gospodarstwa domowe mogły osiągać swój cel i możliwie najwięcej nabywać dóbr na rynkach towarowych muszą najpierw zgromadzić możliwie największe środki finansowej na ich zakup, występując po stronie podaży na rynku pracy. Z kolei przedsiębiorstwa dążą do realizacji możliwie największego zysku. Uzyskują go poprzez sprzedaż gospodarstwom domowym wytworzonych i dostarczonych na rynek dóbr. Jednak aby produkcja w przedsiębiorstwach mogła zaistnieć, niezbędne jest wykorzystanie czynników wytwórczych. Zapotrzebowanie na nie zgłaszają przedsiębiorstwa na rynku pracy reprezentując stronę popytową. Wobec tego aby przedsiębiorstwa mogły realizować swój cel maksymalizując zysk muszą uprzednio zaangażować czynniki produkcji na rynku pracy, czyli zająć miejsce po stronie popytu na pracę.

Leon Walras zapisał stan równowagi w postaci złożonego układu równań ale nie przedstawił jednak dowodu matematycznego jej istnienia. Dowód matematyczny istnienia równowagi ogólnej analizowanej przez Leona Walrasa zaprezentowali później dwaj ekonomiści Kenneth J. Arrow i Gerard Debreu. Wykorzystując nowoczesne metody matematyczne, takie jak teoria zbiorów i topologia oraz narzędzia matematyczne rozwinięte przez John F. Nasha, tj. teorię gier - dowiedli, że w warunkach konkurencji istnieje układ cen zapewniający równowagę na wszystkich rynkach. Wykazali, ,że nawet gdy liczba czynników produkcji i produktów sięga milionów, to przy pewnych założeniach ograniczających będzie istniało co najmniej jedno rozwiązanie układu równań w postaci zbioru cen zrównującego każdy popyt $\mathrm{z}$ odpowiadającą mu podażą" ${ }^{10}$. Mimo iż model ten stanowi zbiór rozwiązywalnych matematycznie równań to głównie z powodu założeń ograniczających między innymi takich jak: całkowita elastyczność płac i cen, nieistnienie monopoli i oligopoli, brak efektów zewnętrznych negatywnych oraz neutralność pieniądza (tzn. brak wpływu pieniądza na

${ }^{10}$ Stownik historii myśli ekonomicznej..., op. cit., s. 38. 
poziom produkcji) nie dowodzi on, ,że w realnej gospodarce swobodna gra sił rynkowych zawsze będzie prowadzić do równowagi" ${ }^{11}$. Istotnym jest jednak, że model ten „dowodzi, że każda sytuacja równowagi mechanizmu rynkowego jest optymalna w sensie Pareta. Każdy stan gospodarki optymalnej w sensie Pareta może być zrealizowany jako stan równowagi mechanizmu rynkowego" ${ }^{12}$.

Kolejnym ekonomistą, który w historii myśli ekonomicznej podejmował rozważania na temat równowagi był Alfred Marshall, znany $\mathrm{z}$ teorii równowag cząstkowych. Jego analizy dotyczyły głównie zakresu mikroekonomicznego i opierały się na wykorzystaniu metody ceteris paribus, która pozwoliła także w sposób bardzo przystępny przedstawić graficznie model rynku. Jak zauważył Bartkowiak „w modelu tym Marshall połączył podejście podażowe klasyków ekonomii, wskazujących koszty produkcji jako czynnik cenotwórczy, z podejściem popytowym marginalistów, uznających użyteczność za czynnik cenotwórczy” ${ }^{13}$. Jednocześnie „Marshall wykazał, że żadna z dwóch teorii wartości i cen nie jest ani w pełni poprawna, ani w pełni błędna. Dla każdej z nich druga wskazuje czynnik ograniczający. Dla czynnika kosztowego (podażowego) kształtowania się ceny jest nim popyt, a dla czynnika popytowego - koszt"14. Równowaga rynku w ujęciu graficznym została zaprezentowana na rys. 2 .

$$
\begin{aligned}
& \mathrm{P} \text { - cena, } \\
& \mathrm{Q} \text { - ilość, } \\
& \mathrm{D} \text { - krzywa popytu, } \\
& \mathrm{S} \text { - krzywa podaży, } \\
& \mathrm{E} \text { - punkt równowagi rynku, } \\
& \mathrm{Pe} \text { - cena równowagi rynku, } \\
& \mathrm{Qe}-\text { ilość równowagi rynku. }
\end{aligned}
$$

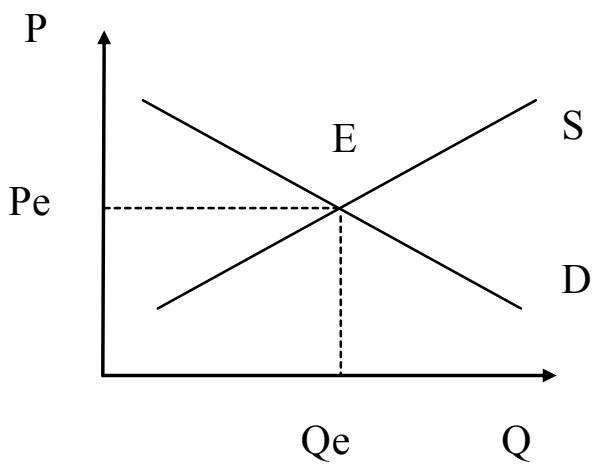

Rysunek 2. Równowaga rynku

Źródło: opracowanie własne na podstawie: Landreth i. Colander, Historia myśli ekonomicznej, Wydawnictwo Naukowe PWN, 2005, s. 334.

\footnotetext{
${ }^{11}$ Ibidem, s. 39.

${ }^{12}$ Ibidem, s. 39.

${ }^{13}$ R. Bartkowiak, Historia myśli ekonomicznej..., op. cit., s. 113-114.

${ }^{14}$ Ibidem, s. 114.
} 
Przedstawiona na rys. 2 krzywa popytu oznaczona symbolem D opisuje zależność między ceną danego dobra, a jego ilością nabywaną przez konsumentów. Z kolei krzywa podaży oznaczona symbolem $\mathrm{S}$ obrazuje zależność między ceną danego dobra a jego ilością oferowaną przez producentów. Przy tym jak podkreślili Landreth i Colander „Marshall rozpatrywał schematy popytu jako wskaźniki maksymalnych cen, które jednostki byłyby gotowe płacić za daną ilość towaru. Ilość jest więc zmienną niezależną, a cena popytu zmienną zależną. $Z$ drugiej strony, jeśli chodzi o schematy podaży, to wskazują one minimalną cenę, za którą sprzedawcy byliby gotowi dostarczyć daną ilość towaru. Znowu więc ilość jest zmienną niezależną, a cena zmienną zależną"15. Dlatego Alfred Marshall traktując ilości jako zmienne niezależne omawiał procesy dostosowawcze związane $\mathrm{z}$ dochodzeniem do równowagi w kategoriach dostosowań ilości. Dostosowania na rynku prowadzą do stanu równowagi rynku, który zobrazowany jest na rys. $2 \mathrm{w}$ punkcie oznaczonym symbolem E. Tylko w tym miejscu dochodzi do spotkania krzywej popytu z krzywą podaży. Zatem przy tej jednej cenie oznaczonej symbolem Pe określanej ceną równowagi rynku, ilość oferowana przez producentów (sprzedawców) wynosi dokładnie tyle co ilość nabywana przez konsumentów.

Przedstawione dotychczas rozważania o równowadze w ujęciu ekonomistów zaliczanych do nurtu klasycznego stanowiły główne pole krytyki dla kolejnego ekonomisty Johna M. Keynesa, którego poglądy na temat równowagi i mechanizmów gospodarczych były zgoła odmienne ${ }^{16}$. Analizy Johna Keynesa cechowały zarówno zmiana podejścia do podstawowych kategorii ekonomicznych - ujęcia krótkookresowe iw skali makroekonomicznej - jak również zwrócenie uwagi w kierunku znaczenia jeszcze innych kategorii, dotychczas rzadziej analizowanych i opisywanych. Jego rozważania o równowadze sprowadzały się przede wszystkim do dostrzegania jej braku w realnej gospodarce. Według Keynesa „w gospodarce nie działają siły

${ }^{15}$ H. Landreth, D.C. Colander, Historia myśli ekonomicznej, Wydawnictwo Naukowe PWN, 2005, s. 334

${ }^{16}$ Aby to dostrzec warto w tym miejscu przytoczyć gówne cechy teoretyczne ekonomii Keynesowskiej. Należą do nich: 1. „Zmiana metody z mikroekonomicznej na makroekonomiczną, przejście od długiego do krótkiego okresu, od analizy w kategoriach realnych do analizy w kategoriach pieniężny ch oraz od zmian cen do zmian ilości jako głównych przedmiotów analizy. 2. Przyjmuje się, że zarówno łączna konsumpcja, jak i łączne oszczędności są stabilnymi funkcjami dochodu, ale inwesty cje traktuje się jako, przynajmniej częściowo, autonomiczne, z samej swej natury zmienne oraz stale podlegające niep ewności. 3. O oszczędnościach i inwestycjach twierdzi się, że różniludzie dokonują ich z różny ch powodów, a do stanu równowagi doprowadzająje dopiero zmiany samego dochodu. 4. Stopę procentową wyjaśnia się w kategoriach pieniężnych jako funkcję zasobowego popytu na pieniądz pozostającą $\mathrm{w}$ interakcji z egzogenicznie wyznaczoną podażą pieniądza. 5. Twierdzi się, że płace realne są wyznaczane przez wolumen zatrudnienia, a nie na odwrót.” M. Blaug, Teoria ekonomii..., op. cit., s. 685-686. 
prowadzące do ustalenia się stanu równowagi przy pełnym wykorzystaniu czynników produkcji. Osiągnięcie takiego stanu można wythumaczyć jedynie przypadkiem, a i wtedy nie będzie się on utrzymywał przez dłuższy okres. Pojęcie równowagi pojmuje Keynes w sposób węższy. Mianowicie, równowagą jest dla niego tylko równowaga między globalną podażą, a globalnym popytem. Taka równowaga może się jednak ustalić przy różnych stopniach wykorzystania produkcyjnych zdolności gospodarki. W stanie równowagi w ujęciu Keynesa mogą więc istnieć zarówno niewykorzystane zdolności wytwórcze, jak i niepełne zatrudnienie" ${ }^{" 17}$. Zatem jak podkreślił również Bartkowiak ,... według Keynesa immanentną cechą gospodarki jest brak (...) równowagi, ponieważ prawo rynków nie jest prawdziwe ${ }^{18}$ ".

W odróżnieniu od klasycznych poprzedników John Keynes zwrócił uwagę na znaczenie popytu - w ujęciu makroekonomicznym oraz czynniki go określające popyt konsumpcyjny i inwestycyjny. Określił psychologiczne prawo opisujące skłonność jednostek do konsumowania i oszczędzania ${ }^{19}$. Wyróżnił krańcową skłonność do konsumpcji, która identyfikuje jaką część przyrostu swojego dochodu gospodarstwa domowe przeznaczają na przyrost konsumpcji. Jednocześnie przedstawił konsumpcję i oszczędności jako funkcje produktu (dochodu). Przy tym zarówno konsumpcja jak i oszczędności wzrastają wraz ze wzrostem produktu w określonych współczynnikami proporcjach. Według Keynesa to ile społeczeństwo wydaje na konsumpcję zależy po części od wielkości dochodu, innych okoliczności natury obiektywnej oraz subiektywnych potrzeb, skłonności psychicznych, zwyczajów jednostek oraz zasad, według których dochód jest między nie podzielony ${ }^{20}$.

Przyjmując przedstawione powyżej pojęcia za podstawę swoich rozważań Keynes stwierdzit, że „stan równowagi gospodarki kapitalistycznej, opierający się na równości ex ante oszczędności i inwestycji $\mathrm{S}=\mathrm{I}$, jest raczej czymś wyjątkowym" ${ }^{21}$. Wskazał bowiem, mało prawdopodobne w praktyce, warunki stabilizacji systemu dla jej uzyskania, do których zaliczy $\mathrm{f}^{22}$ :

1) krańcowa skłonność do konsumpcji musi być taka, aby pod wpływem zmian w produkcji i zatrudnieniu mnożnik był większy od jedności, ale także niezbyt wielki,

\footnotetext{
${ }^{17}$ J. Górski, W. Sierpiński, Historia powszechnej myśli ekonomicznej..., op. cit., s. 326.

${ }^{18}$ R. Bartkowiak, Historia myśli ekonomicznej..., op. cit., s. 216.

${ }^{19}$ Ibidem, s. 189.

${ }^{20}$ J. M. Keynes, Ogólna teoria zatrudnienia, procentu i pieniq̨dza, Wydawnictwo Naukowe PWN, Warszawa 2003, s. 82.

${ }^{21}$ W. Stankiewicz, Historia myśli ekonomicznej, Polskie Wydawnictwo Ekonomiczne, War-

${ }^{22}$ Ibidem, s. 296.
} szawa 2007, s. 296. 
2) zmiany w przewidywanej dochodowości kapitału albo w stopie procentowej muszą znajdować pełne odbicie w krzywej krańcowej wydajności kapitału,

3) zmiany rozmiarów zatrudnienia i płac nominalnych powinny być zgodne co do kierunków i proporcji,

4) fluktuacje powinny po pewnym czasie zmieniać kierunek na przeciwny.

Zapoczątkowane przez Keynesa rozważania dotyczące stanów równowagi i nierównowagi w gospodarce, stanowiły asumpt dla innych ekonomistów, którzy albo poprzez potwierdzanie jego refleksji, albo poprzez krytykę kontynuowali podjęte przez niego tematy. Na tej podstawie za pomocą krzyża keynesowskiego Alvin Hansen zilustrował znaczenie popytu w gospodarce, a John Hicks zaproponował model IS-LM.

Model krzyża keynesowskiego jest ilustracją zależności między produkcją (dochodem), a czynnikami go determinującymi. Został zaprezentowany na rys. 3.

\footnotetext{
$\mathrm{AD}$ - popyt zagregowany,

$\mathrm{Y}$ - produkcja (dochód),

$\mathrm{E}$ - punkt równowagi,

Ye - produkcja (dochód) stanu równowagi
}

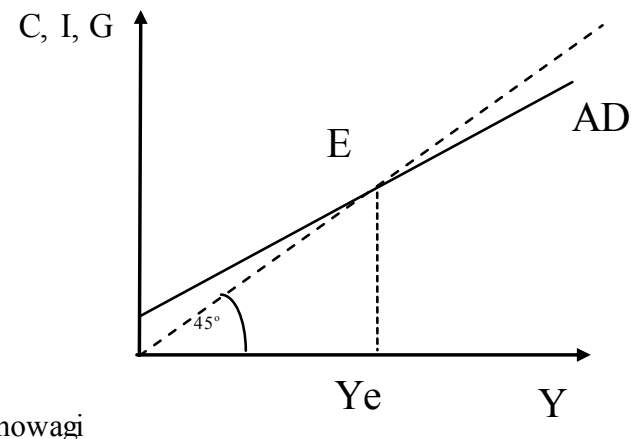

Rysunek 3. Model krzyża keynesowskiego

Źródło: opracowanie własne na podstawie: R. Bartkowiak, Historia myśli ekonomicznej, Polskie Wydawnictwo Ekonomiczne, Warszawa 2003, s. 193.

Model krzyża keynesowskiego, zaprezentowany na rys. 3 pozwala w prosty sposób, przy uwzględnieniu popytu konsumpcyjnego oznaczonego na rysunku symbolem $\mathrm{C}$, inwestycyjnego oznaczonego na rysunku symbolem I oraz popytu państwa ujmowanego jako wydatki rządowe oznaczone symbolem $\mathrm{G}$, zaobserwować stan równowagi w gospodarce oznaczony symbolem $\mathrm{E}$ oraz dwa stany nierównowagi. $\mathrm{Na}$ lewo od punktu równowagi popyt przewyższa podaż. Z kolei na prawo od tego punktu podaż jest większa niż zgłaszany popyt. W przypadku gdy popyt na wytworzone dobra jest mniejszy od ogólnej podaży pojawia się luka deflacyjna i produkt stanu równowagi jest mniejszy od potencjalnego. Jak 
podsumowuje dalej Bartkowiak: „Gospodarka osiąga równowagę (stan pożądany przez klasyków ekonomii), ale jest to równowaga suboptymalna. Występuje ona przy nadwyżce podaży pracy (...) ze strony gospodarstw domowych nad popytem na pracę (...) ze strony przedsiębiorstw, czyli przy przymusowym bezrobociu (...). Skoro sektor prywatny gospodarki nie tworzy popytu wystarczającego do wchłonięcia całego wytworzonego produktu, to dodatkowy popyt zgłasza państwo. Tę wspomagającą działalność państwa nazwano interwencjonizmem. (...) Rosnące wydatki rządowe (państwowe) uruchamiają kolejne fale popytu czyli mechanizm mnożnikowy. (...) Jeżeli impuls pochodzi od dodatkowych wydatków rządowych, jest to mnożnik wydatków rządowych (...). Poziom mnożnika zależy od poziomu współczynnika skłonności do konsumpcji ( w tym przypadku krańcowego). Im skłonność do konsumpcji jest większa, tym efekt mnożnikowy dodatkowych wydatków rz̨adowych jest silniejszy (...)." ${ }^{, 23}$

Z kolei model IS-LM zaproponowany przez Johna Hicksa integruje na jednym układzie współrzędnych sfery realną oraz pieniężną gospodarki ${ }^{24}$. Model zaprezentowano na rys. 4.

$\mathrm{r}$ - stopa procentowa,

Y - produkcja (dochód),

IS - krzywa IS,

LM - krzywa LM,

$\mathrm{E}$ - punkt równowagi,

re - stopa procentowa równowagi,

Ye - produkcja (dochód) równowagi.

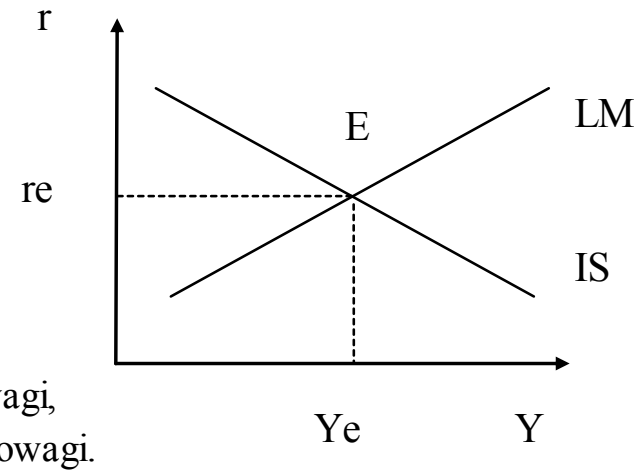

Rysunek 4. Model IS-LM

Źródło: opracowanie własne na podstawie: H. Landreth, D. C. Colander, Historia myśli ekonomicznej, Wydawnictwo Naukowe PWN, 2005, s. 504.

Krzywa, którą na rys. 4 oznaczono symbolem IS reprezentuje sferę realną w postacirynku kapitału i obrazuje wszystkie przypadki kiedy rynek kapitałowy jest w równowadze, czyli gdy inwestycje są równe oszczędnościom. Z kolei krzywa

\footnotetext{
${ }^{23}$ R. Bartkowiak, Historia myśli ekonomicznej..., op. cit., s. 194-195.

${ }^{24}$ Ibidem, s. 203-204.
} 
oznaczona symbolem LM jest reprezentantem sfery pieniężnej gospodarki i przedstawia wszystkie przypadki kiedy rynek pieniężny jest w równowadze, czyli gdy popyt na pieniądz jest równy podaży. Skoro krzywa IS ilustruje równowagę na rynku kapitałowym, a krzywa LM równowagę na rynku pieniężnym, to punkt spotkania tych dwóch krzywych, oznaczony na rysunku symbolem E, stanowi stan równowagi na obu rynkach jednocześnie. Przy pomocy tego modelu można zatem analizować wpływ zmian na jednym z rynków na drugi rynek ${ }^{25}$.

Podsumowując te syntetyczne rozważania wybranych ekonomistów na temat historycznego ujęcia tematu równowagi ekonomicznej należy zauważyć, że każde z zaprezentowanych ujęć i odniesień do równowagi opierało się na określonych założeniach. Dodatkowo niektórzy autorzy tych rozważań podkreślali, że równowaga jest stanem krótkotrwałym, pożądanym, ujęciem modelowym itd. Generuje to przede wszystkim wątpliwości, co do słuszności apoteozy stanu równowagi jako stanu zapewniającego optimum życia gospodarczego.

\section{Równowaga ekonomiczna}

Równowagę ekonomiczną rozpatrywać należy długookresowo, jako pewną tendencję, model, do którego zmierza gospodarka w wyniku działania mechanizmu rynkowego i ekonomicznej polityki państwa. Osiągnięcie i utrzymanie równowagi ekonomicznej jest bardzo trudne, z uwagi na ogromną liczbę czynników, które oddziałują na popyt i podaż na każdym z rynków, wytrącając je stale $\mathrm{z}$ ukształtowanego stanu równowagi.

W literaturze ekonomicznej mówi się o różnych rodzajach równowagi, w zależności od przyjętego obszaru badawczego.

1. Równowaga konsumenta występuje wtedy, gdy stosunek cen dwóch nabywanych przez niego dóbr równa się krańcowej stopie substytucji.

${ }^{25}$ Model IS-LM został skrytykowany przez samego Johna Hicksa bowiem jak opisuje W. Stankiewicz: „Odkryto przede wszystkim, że mamy tu pomieszanie dwóch wymiarów świata ekonomicznego - strumieni i zasobów, a więc dynamiki i statyki, zlekceważenie czynnika czasu. Wszak blok IS opisuje alternatywne stany równowagi dwóch strumieni - inwestycji i oszczędności, natomiast blok LM prezentuje alternatywne równowagi dwóch zasobów - pieniądza transakcyjnego i spekulacyjnego. Dla strumieni istotne znaczenie ma przedział czasu, dla zasobów wystarczy określenie momentu czasu. Hicks próbował usunąć tę sprzeczność, wprowadzając własne określenie „okresu” jako krótkiego przepływu czasu między przeszłością a przyszłością. W praktyce taki okres może być ty godniem lub nawet mementem (punktem) czasu. Rynki w takim okresie mogą mieć ceny sztywne i nierównowagę podaży z popytem. W. Stankiewicz, Historia myśli ekonomicznej..., op. cit., s. 301. 
2. Przedsiębiorstwo jest $\mathrm{w}$ równowadze, gdy osiąga zysk maksymalny, to jest wówczas, gdy koszt krańcowy równa się utargowi krańcowemu.

3. Gałąź przemysłu jest w równowadze, gdy nie ma powodów ani do wzrostu liczby przedsiębiorstw w tej gałęzi, ani do likwidacji któregokolwiek z już istniejących przedsiębiorstw.

4. Cały rynek jest w równowadze, gdy przy istniejących cenach ogólna podaż towarów i usług równa się ogólnemu popytowi na nie (choć może występować nierównowaga cząstkowa).

5. Równowaga stała występuje wówczas, gdy zmiana jakiegoś czynnika wytwórczego spowodowana impulsem zewnętrznym jest po pewnym czasie wyeliminowana przez zmiany działające $\mathrm{w}$ kierunku przeciwnym, tak że następuje powrót do stanu poprzedniego.

6. Równowaga zmienna oznacza sytuację, w której zmiana któregoś z czynników wytwórczych powoduje trwałe odejście od poprzedniego stanu równowagi i dochodzi do innego stanu równowagi.

Równowaga ogólna jest to stan gospodarki, w którym zachowana jest równowaga globalnego popytu i globalnej podaży na wszystkich rynkach:

- wytworzonych dóbr w określonym czasie,

- świadczonych usług,

- czynników wytwórczych (równowaga rynkowa), a także

- w wymianie z zagranicą.

Sytuacja taka oznacza jednocześnie występowanie równowagi wewnętrznej i równowagi zewnętrznej.

\subsection{Warunki równowagi ogólnej}

Równowaga ogólna w gospodarce danego kraju ma miejsce wówczas, gdy globalny (zagregowany) popyt, odpowiadający poziomowi i strukturze potrzeb społeczeństwa przy danych jego dochodach i indeksach cen rynkowych, zrównuje się z globalną (zagregowaną) podażą towarów i usług, odpowiadającą poziomowi i strukturze produkcji wynikającej z popytu na niezbędne do jej wytworzenia czynniki produkcji przy danym indeksie ich cen rynkowych i określonej ich podaży $\mathrm{w}$ danym przedziale czasu.

Jeżeli wartość $\mathrm{PKB}$ równa $\mathrm{Q}$ x $\mathrm{P}$

oznacza zagregowaną podaż AS,

a wartość wydatków konsumentów na spożycie - K,

wartość wydatków na cele inwestycyjne - I, 
które łącznie stanowią zagregowany popyt - $\mathrm{AD}$,

to wówczas równowaga zostanie zachowana przy spełnieniu następującego warunku:

$$
\mathrm{P} \times \mathrm{Q}=\mathrm{K}+\mathrm{I}
$$

lub

$$
\mathrm{AS}=\mathrm{AD}
$$

Jest to równowaga ogólna przy abstrakcyjnym założeniu braku udziału państwa w kształtowaniu procesów gospodarczych. Jeżeli jest spełniony warunek, że w kolejnych latach tempo wzrostu PKB jest dodatnie, a wartość produkcji pokrywa wartość wydatków konsumpcyjnych i inwestycyjnych, a więc:

$$
\mathrm{AS} 1=\mathrm{AD} 1, \quad \mathrm{AS} 2=\mathrm{AD} 2, \quad \mathrm{ASn}=\mathrm{ADn},
$$

to wówczas ma miejsce zrównoważony wzrost gospodarczy.

\subsection{Warunki równowagi ogólnej}

Niezrównoważony wzrost gospodarczy, to taki proces rozwojowy, w którym ma miejsce dodatnie tempo wzrostu gospodarczego i nie są spetnione warunki równowagi ogólnej, co oznacza, że wartość PKB odpowiadająca podaży AS jest większa od wydatków na konsumpcję $\mathrm{K}$ i inwestycje I, a więc jest większa od wartości globalnego popytu, czyli:

$$
\mathrm{AS}>\mathrm{AD}, \quad \mathrm{AS}>\mathrm{K}+\mathrm{I} .
$$

Jeżeli globalna podaż AS jest wyższa od globalnego popytu, wówczas producenci nie mogą sprzedać w całości wytworzonej produkcji. Konsekwencją takiej sytuacji jest zwiększanie zapasów. Zwiększone zapasy oznaczają zamrożenie kapitału towarowego, który nie może być zamieniony na pieniężny z powodu niedostatecznego popytu. Utrzymywanie nadmiernych zapasów jest dla przedsiębiorstw kosztowne, bo roczne ich magazynowanie kosztuje co najmniej jedną trzecią część całkowitej wartości przechowywanych towarów. $Z$ tego powodu powstanie, a zwłaszcza narastanie, przewagi podaży nad popytem jest dla przedsiębiorców sygnałem o konieczności ograniczenia produkcji.

\subsection{Wzrost niezrównoważony przy przewadze popytu}

Niezrównoważony wzrost gospodarczy ma miejsce również wtedy, gdy w gospodarce występuje wprawdzie dodatnie tempo wzrostu PKB, ale odpowiadająca PKB wartość podaży AS jest mniejsza od popytu:

$$
\mathrm{AD}=\mathrm{K}+\mathrm{I}, \quad \text { czyli } \quad \mathrm{AS}<\mathrm{AD} .
$$


Taka sytuacja oznacza, że część nabywców nie będzie mogła nabyć towarów, bo ich zapasy uległy nadmiernemu zmniejszeniu. Wówczas nie jest możliwe zaspokojenie globalnego popytu $\mathrm{w}$ gospodarce. Przedsiębiorstwa przymusowo rezygnują z części odbiorców. Zdają sobie sprawę, że taka sytuacja jest dla nich niekorzystna, gdyż niedobory będą uzupełniane niezbędnym importem, co może oznaczać trwałe zmniejszenie ich udziału w rynku. Z tego powodu zarówno zmniejszenie zapasów towarów w systemie handlu hurtowego, jak i odnotowywana przewaga popytu nad podażą, są dla przedsiębiorców sygnałami, które zachęcają ich do zwiększenia produkcji towarów i szybkiego przywracania równowagi.

\subsection{Ocena systemów gospodarczych}

System gospodarczy składa się z organizacji i tworzących je jednostek, które działają w czasie. Organizacje, instytucje i jednostki są powiązane między sobą przepływami produktów i informacji. Działanie systemu gospodarczego jest określone przez funkcje jednostek wchodzących w skład systemu.

Wszystkie systemy gospodarcze można podzielić na: gospodarkę wolnorynkową, gospodarkę rynkową mieszaną, gospodarkę centralnie kierowaną.

Ocena systemów gospodarczych nie jest zadaniem łatwym i jednoznacznym. Do ich oceny można posłużyć się ogólnymi cechami, wywierającymi zasadniczy wpływ na ludzi żyjących w różnych systemach gospodarczych. J. Kornai ${ }^{26}$ zaproponował dokonywanie oceny systemów gospodarczych $\mathrm{w}$ oparciu o następujące kryteria:

- realny wzrost systemu gospodarczego, tzn. wzrost produkcji, dochodu narodowego, konsumpcji oraz wolumenu mocy produkcyjnych,

- postęp techniczny; system powinien zapewniać (stymulować) wprowadzanie nowych wynalazków (nowe produkty, nowe sposoby postępowania, nowe technologie),

- przystosowawcze własności systemu oznaczają dolność adaptacyjną systemu do koniecznych zmian produkcji i konsumpcji oraz sposobu funkcjonowania systemu;

- selekcyjne właściwości systemu w odniesieniu do nowo pojawiających się organizacji oraz osób zajmujących kierownicze stanowiska $\mathrm{w}$ organizacji (chodzi o przedsiębiorczość, zdolności organizacyjne, zdyscyplinowanie);

${ }^{26}$ J. Kornai, Anti-Equilibrium. Teoria systemów gospodarczych. Kierunki badań, PWN, Warszawa 1975 , s. 282-286. 
- podział dochodu i zatrudnienia; sprzeczność między bodźcowym a egalitarnym podziałem oraz konieczność zapewnienia zatrudnienia dla wszystkich chcących pracować;

- rozwój kulturalny i społeczny, dotyczy to między innymi zapewnienia rozwoju nauki, wydłużenia okresu nauczania, poprawy usług służby zdrowia itp.;

- własność, władza i decyzje, chodzi o sprzeczności, jakie mogą występować w organizacji, problem centralizacji i decentralizacji zarządzania gospodarką, sposób wyrażania woli społeczeństwa, zakres wolności itp.

Krytyczną ocenę współczesnej gospodarki rynkowej przedstawił Witte ${ }^{27}$ akcentując jednocześnie środki zaradcze $\mathrm{w}$ zmianach strukturalnych prowadzących do urzeczywistnienia zrównoważonej gospodarki rynkowej, co przejawia się w następujących postulatach:

- konieczności wprowadzenia nowego systemu pieniądza,

- likwidacji zadłużenia państwa,

- likwidacji subwencji,

- dominacji systemu suprastruktury,

- wprowadzenia kooperacji zamiast współzawodnictwa,

- wprowadzenia nowego systemu prawnego,

- nowego systemu politycznego, a w szczególności określenia zadań państwa, zadań obywateli, zadań przedsiębiorstw,

- dostosowania zakładowej rachunkowości do potrzeb makroekonomicznych.

\subsection{Równowaga rynkowa}

Równowaga rynkowa jest to sytuacja, w której wszystkie siły rynkowe równoważą się, a wartość zmiennych ekonomicznych pozostają niezmienne. W szczególności, najczęściej mianem równowagi rynkowej określa się stan rynku, w którym ilość dóbr nabywanych przez konsumentów równa się ilości tych dóbr wytwarzanych przez producentów, czyli stan w którym wielkość popytu na danym rynku jest równa wielkości podaży. Czynnikiem równoważącym podaż i popyt jest zazwyczaj cena. Cena, przy której występuje równowaga rynkowa nazywana ceną równowagi rynkowej. Graficznym odzwierciedleniem stanu równowagi rynkowej jest punkt równowagi rynkowej, czyli punkt przecięcia się krzywej popytu z krzywą podaży, który został zaprezentowany na rys. 5.

27 H. Witte, Die nachhaltige Marktwirtschaft. Wohlstand ohne self-made Krisen,? LIT VERLAG, Berlin 2013, s. 154-165. 


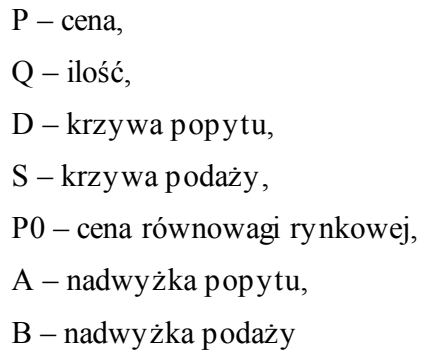

Rysunek 5. Równowaga rynkowa

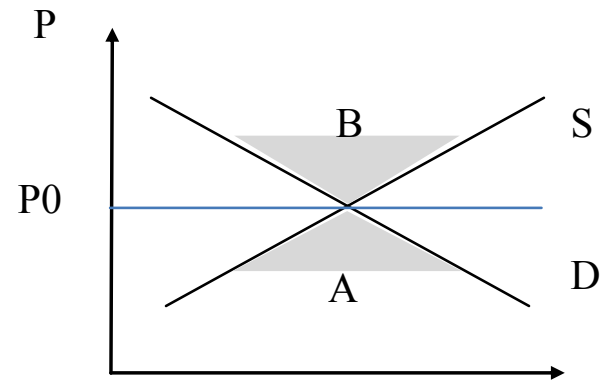

Q

Ilość dobra opisywana jest na osi odciętych (oś pozioma), zaś cena jednostkowa tego dobra mierzona jest na osi rzędnych (oś pionowa). Krzywa popytu oznaczona jest literą $\mathrm{D}$, a krzywa podaży literą S. Przy cenie P0, wielkość popytu jest równa wielkości podaży, a zatem ma miejsce równowaga rynkowa, i cena równowagi rynkowej jest równa P0. Gdy cena jest mniejsza od ceny równowagi rynkowej ma miejsce nadwyżka popytu nad podażą, co ilustruje obszar A. Zazwyczaj w sytuacji takiej mechanizm rynkowy prowadzi do wzrostu ceny do wartości P0. W sytuacji, gdy cena przewyższa cenę równowagi rynkowej, ma miejsce nadwyżka podaży nad popytem, co ilustruje obszar B. W takiej sytuacji mechanizm rynkowy prowadzi do spadku ceny w kierunku ceny równowagi rynkowej P0.

Przy cenach rynkowych wyższych od ceny równowagi pojawia się nadwyżka podaży nad popytem, ceny rynkowe niższe od ceny równowagi powodują powstanie nadwyżki popytu nad podażą, co na rynku przejawia się w postaci niedoborów określonych dóbr. Wystąpienie nadwyżki rynkowej, będącej rezultatem zwiększenia się podaży lub zmniejszenia popytu pod wpływem innych niż cena czynników, uruchamia procesy dostosowawcze, polegające na obniżaniu ceny przez sprzedawców, w rezultacie czego rozmiary popytu rosną, a zmniejsza się wielkość podaży. Proces ten trwa dotąd, dopóki nie nastąpi ich zrównanie. W przypadku niedoboru rynkowego sprzedawcy podwyższają cenę tak długo, aż zmniejszająca się wielkość popytu i rosnąca wielkość podaży doprowadzą do ustalenia ceny równowagi.

Analogiczne zasady kształtowania równowagi rynkowej występują także na rynkach czynników produkcji, z tym, że na rynku pracy rolę ceny pełni płaca, na rynku finansowym - stopa procentowa, a na rynku ziemi i innych nieruchomości może ją pełnić renta gruntowa. 


\subsection{Równowaga ogólna a równowagi cząstkowe}

Występowanie w gospodarce narodowej stanu równowagi ogólnej nie oznacza, że jest ona zachowana w poszczególnych sektorach, działach czy gałęziach gospodarki. Równowaga w mniejszych segmentach niż cała gospodarka, określana jest jako równowaga cząstkowa. Jeżeli zachowane są równowagi cząstkowe między podażą i popytem na wszystkie rodzaje towarów i usług, to w gospodarce narodowej ma miejsce równowaga ogólna. Natomiast nie jest prawdziwe twierdzenie odwrotne, ponieważ przy nadwyżce np. podaży nad popytem na produkty rolne czy siłę roboczą i jednocześnie utrzymywaniem się nadwyżki popytu nad podażą na mieszkania i usługi edukacyjne, równowaga ogólna w gospodarce może być zachowana. Dla utrzymania równowagi ogólnej w gospodarce ważne jest, aby suma nadwyżek podaży nad popytem na pewne towary kompensowała się sumą jej niedoborów na inne towary i usługi.

Kształtowanie się zależności między globalną podażą, a poziomem cen pokazuje, że spadek początkowego poziomu cen wywołuje spadek produkcji, zmniejszenie zatrudnienia i wykorzystania potencjalnych zdolności wytwórczych, a w rezultacie spadek podaży. Tendencja zaś wzrostu przeciętnego poziomu cen wywołuje wzrost produkcji, wzrost zapotrzebowania na rzeczowe czynniki produkcji i siłę roboczą, a tym samym wzrost podaży.

Popytowy wymiar rynku, podobnie jak podażowy, jest zależny od średniego poziomu cen. Spadkowa tendencja średniego poziomu cen na towary i usługi wywołuje wzrost siły nabywczej ludności, a więc efektywnego popytu. Oprócz średniego poziomu cen i tendencji ich zmian, na równowagę wpływają też inne czynniki, takie jak: zwiększenie ilości pieniądza w obiegu, wzrost lub spadek wydatków rządowych, wzrost lub spadek optymizmu przedsiębiorców.

\subsection{Równowaga wewnętrzna a równowaga zewnętrzna}

Oprócz równowagi wewnątrzkrajowej wyróżnia się równowagę zewnętrzną. Równowagę zewnętrzną gospodarka osiąga wówczas, gdy saldo obrotów bieżących bilansu płatniczego jest równe zero. Gospodarka danego kraju osiąga stan równowagi długookresowej wówczas, gdy spełnione są w niej jednocześnie warunki równowagi wewnętrznej i zewnętrznej. Osiągnięcie tego stanu nie jest łatwe, ponieważ w gospodarce funkcjonują jednocześnie miliony jednostek gospodarczych i miliony gospodarstw domowych. Przebiegają w nich i między nimi różnorodne, skomplikowane procesy dostosowawcze, które powodują takie zmiany zapasów i przepływu strumieni, zarówno w całej gospodarce, jak 
iw poszczególnych jej segmentach, które w gruncie rzeczy polegają na naruszaniu i przywracaniu równowagi.

\subsection{Kształtowanie równowagi w gospodarce}

W gospodarce równowaga jest stanem przejściowym. Regułą jest proces jej naruszania i przywracania. Zdolności samoregulacyjne gospodarki rynkowej są ograniczone i nie tak precyzyjne, jak np. w systemach technicznych, w których określonej wartości bodźca odpowiada jednocześnie określona, oczekiwana wartość efektu. W gospodarce natomiast wielość i zmienność czynników oddziałujących na równowagę powoduje, że trudno ją trwale utrzymać i w pełni skutecznie sterować procesami, które na nią oddziałują.

W gospodarce rynkowej proces kształtowania równowagi jest samoregulacyjny, ale w znacznym stopniu ma charakter żywiołowy. $Z$ tego powodu dochodzenie zarówno do równowagi ogólnej, jaki do równowag cząstkowych na rynku dóbr konsumpcyjnych, na rynku dóbr inwestycyjnych i na rynku pracy oraz w stosunkach ekonomicznych $\mathrm{z}$ otoczeniem zagranicznym odbywa się za pomocą wielu podmiotów i sił, o zmiennej intensywności i różnym zakresie ich oddziaływania oraz skali skutków dla stanu gospodarki w określonym czasie.

\subsection{Równowaga przedsiębiorstwa w warunkach konkurencji doskonałej}

Konkurencja doskonała istnieje wtedy, gdy spełnione są następujące warunki:

1. Na rynku występuje duża liczba kupujących i sprzedających. Każdy z producentów wytwarza znikomą część łącznej produkcji. Zmiana wielkości ich produkcji nie wpływa na podaż. Producenci nie mają wpływu na ceny - cena jest niezależna od producenta.

2. Istnieje doskonała mobilność czynników produkcji (swobodny przepływ między poszczególnymi gałęziami produkcji) oraz możliwość zakładania nowych przedsiębiorstw. Nie ma barier wejścia na rynek.

3. Oferowane do sprzedaży towary i usługi mają jednakowe (zbliżone) cechy użytkowe. Reklama i marka firmowa nie odgrywają żadnej roli.

4. Kupujący i sprzedający mają doskonałą znajomość rynku (dysponują informacją). Oznacza to, że producenci mają pethe rozeznanie dotyczące cen, kosztów i możliwości sprzedaży na rynku, a konsumenci mają pełne informacje o cenach, jakości i dostępności dóbr i usług. 
Równowaga przedsiębiorstwa jest to stan, w którym przedsiębiorstwo osiągnęlo maksymalny stopień realizowanej funkcji celu w danym horyzoncie czasowym i w określonych warunkach zewnętrznych. Funkcją celu przedsiębiorstwa w gospodarce rynkowej jest: kwota zysku - w krótkim okresie, stopa zysku - w długim okresie.

Można zatem zapisać

$$
\mathrm{Zc}=\mathrm{Uc}-\mathrm{Kc}
$$

oraz

$$
\mathrm{Zs}=\mathrm{Zc}: \mathrm{Kc}
$$

gdzie:

Zc-zysk całkowity,

Uc - utarg (przychód) całkowity,

Kc - koszty całkowite,

Zs - stopa zysku.

Stan równowagi przedsiębiorstwa uwarunkowany jest działaniem wielu czynników, które umownie można zaliczyć do dwóch grup, a mianowicie: czynników wewnętrznych (decydujących o poziomie kosztów), czynników zewnętrznych (wpływających na poziom utargu).

W warunkach rynku konkurencji doskonalej pojedyncze przedsiębiorstwo nie ma wpływu na cenę sprzedaży. Cena ustalana jest na rynku jako wypadkowa łącznych rozmiarów podaży i popytu. Przyjąć należy zatem, że cena $(\mathrm{P})$ jest w krótkim okresie wielkością stałą. Jeżeli cena jest stała, to utarg (przychód) całkowity rośnie wraz ze wzrostem sprzedaży, czyli:

$$
\mathrm{Uc}=\mathrm{P} \times \mathrm{Q}
$$

gdzie:

Uc - utarg (przychód) całkowity,

$\mathrm{P}$ - cena,

Q - ilość sprzedanych produktów lub usług.

Utarg przeciętny (Up) jest równy stosunkowi utargu całkowitego przez ilość sprzedanych produktów:

$$
\mathrm{Up}=\mathrm{Uc}: \mathrm{Q}
$$

natomiast utarg krańcowy stanowi przyrost utargu całkowitego związany ze wzrostem sprzedaży o jedną dodatkową jednostkę, czyli:

$$
\mathrm{Uk}=\mathrm{Uc}: \mathrm{Q}
$$

gdzie:

Uk - utarg krańcowy, 
Uc - przyrost utargu całkowitego,

$\mathrm{Q}$ - przyrost sprzedanej jednostki produktu.

Przedsiębiorstwo maksymalizuje zysk przy rozmiarach produkcji wyznaczonych przez punkt zrównania się kosztu krańcowego z utargiem krańcowym, który równy jest cenie.

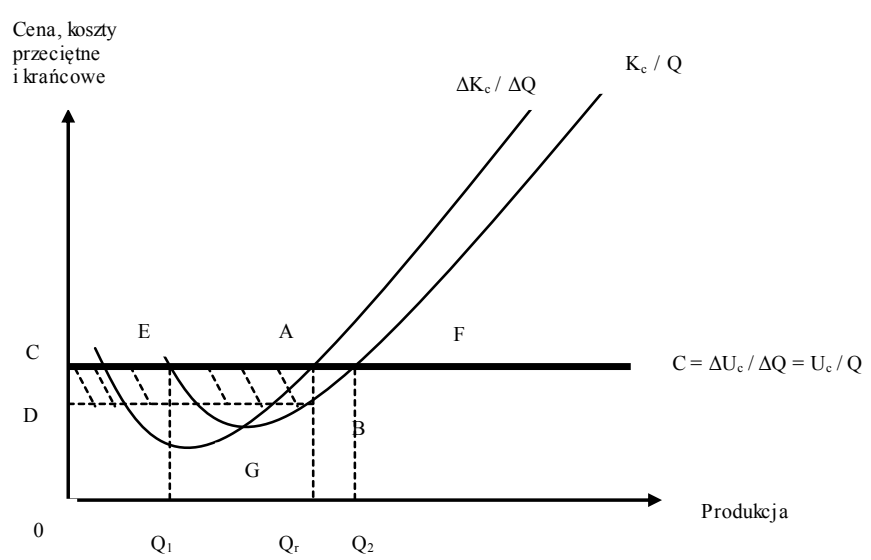

Rysunek 6. Krótkookresowa równowaga przedsiębiorstwa w warunkach konkurencji doskonałej

Rysunek 6 ilustruje krzywą kosztu przeciętnego zrównującą się w punktach E i F z utargiem przeciętnym, który z kolei równy jest utargowi krańcowemu i cenie. Punkty te wyznaczają przedział opłacalnej produkcji mieszczący się między $\mathrm{Q}_{1}$ i $\mathrm{Q}_{2}$. Od punktu $\mathrm{E}$, któremu odpowiada produkcja $\mathrm{Q}_{1}$, przedsiębiorstwo zaczyna przynosić zysk. Punkt ten w związku z tym nazywa się progiem rentowności. Dopóki koszt krańcowy jest niższy od kosztu przeciętnego, zwiększenie produkcji obniża koszt przeciętny i przyczynia się do zwiększenia zysku. W punkcie G, który jest najniższym punktem krzywej kosztu przeciętnego, koszt krańcowy zrównuje się z kosztem przeciętnym. Od tego punktu koszt krańcowy przewyższa koszt przeciętny, a zatem przyczynia się do jego wzrostu. Zysk przedsiębiorstwa rośnie jednak nadal tak długo, jak długo koszt krańcowy zrównuje się $\mathrm{z}$ utargiem krańcowym (i ceną), przedsiębiorstwo osiąga maksimum zysku. $\mathrm{Z}$ tego powodu można stwierdzić, że punkt A wyznacza optimum ekono- 
miczne przedsiębiorstwa. Punkt ten, któremu odpowiada poziom produkcji $\mathrm{Q}_{\mathrm{r}}$, nazywany jest też punktem równowagi przedsiębiorstwa.

\section{Równowaga ekonomiczna $\mathrm{z}$ punktu widzenia zrównoważonego rozwoju w rozumieniu Organizacji Narodów Zjednoczonych}

Ekonomiczny sens działalności człowieka bazuje na wykorzystywaniu ograniczonych zasobów w celu zaspokajania nieograniczonych potrzeb ludzkich. Realizacja tej aktywności powoduje skutki, które niejednokrotnie przekładają się w sposób negatywny na stan środowiska naturalnego. Zdecydowane zwrócenie uwagi na ten fakt i wskazanie konieczności uwzględniania także potrzeb przyszłych pokoleń ma stosunkowo młodą historię. Zainteresowanie wpływem nadmiernej eksploatacji zasobów na stan ekosystemu zapoczątkowane zostało pod koniec lat 60. XX stulecia. Najpierw były to pojedyncze głosy, które sygnalizowały problemy związane $\mathrm{z}$ wyniszczającą działalnością człowieka. Potem w latach 70. i 80. rangi tym głosom nadały konkretne spotkania w słusznej sprawie na arenie międzynarodowej oraz płynące $\mathrm{z}$ nich wnioski i rekomendacje. Określono wówczas przede wszystkim główne zagrożenia oraz wskazano postulaty ich ograniczania, a także uściślono kierunek rozwoju społeczeństwa przemysłowego zdefiniowany jako sustainable development czyli rozwój zrównoważony. Stopniowo podmioty i organizacje światowe, ponadnarodowe, narodowe, regionalne i lokalne umieszczały ideę zrównoważonego rozwoju w centralnym miejscu swoich aktów normatywnych oraz przygotowywały programy wdrożeniowe ${ }^{28}$. Dążenie do realizacji założeń rozwoju zrównoważonego jest zadaniem niezwykle trudnym i złożonym. Implikuje często konieczność głębokich zmian. Nie ulega jednak wątpliwości, że równowaga jako stan gospodarki, rynków funkcjonujących w jej ramach, jak i poszczególnych podmiotów sprzyja efektywnemu wykorzystywaniu zasobów oraz racjonalnemu zaspokajaniu potrzeb, wpisuje się zatem także w sens idei zrównoważonego rozwoju, choć wydaje się, że znaczenie zrównoważenia ma tutaj dużo szersze znaczenie.

Wiodącą organizacją podejmującą problemy związane z potrzebą dążenia do zrównoważonego rozwoju jest Organizacja Narodów Zjednoczonych. To w ramach tej organizacji zainicjowano ogólnoświatowy dyskurs w tym temacie.

${ }^{28}$ H. Rogall, Ekonomia zrównoważonego rozwoju. Teoria i praktyka, Zysk i S-ka Wydawnictwo, Poznań 2010, s. 23-24. 
Definicja zrównoważonego rozwoju, często uznawana za pierwotną, sformułowana została w ramach prac Światowej Komisji ds. Środowiska i Rozwoju Organizacji Narodów Zjednoczonych. Komisja w roku 1987 opublikowała raport pod tytułem „Nasza wspólna przyszłość” (Our Common Future) potocznie nazywany „raportem Brundtland” ${ }^{29}$, w którym określiła, że rozwój zrównoważony to „rozwój, który zaspokaja obecne potrzeby bez ograniczenia możliwości ich zaspokajania przez przyszle pokolenia. W swej istocie oznacza to taki proces zmian, w którym eksploatacja zasobów, kierunki inwestowania i postępu technicznego oraz zmiany instytucjonalne pozostają $\mathrm{w}$ harmonii i zachowują teraz i w przyszłości możliwość zaspokojenia ludzkich potrzeb i aspiracjï ${ }^{30}$. Dodatkowo $\mathrm{w}$ raporcie stwierdzono, że cywilizacja osiągnęła poziom dobrobytu, który jest możliwy do utrzymania pod warunkiem właściwego gospodarowania. Oznacza to, że główne założenia modelu gospodarki realizującej ideę zrównoważonego rozwoju sprowadzają się do odpowiedniego i świadomego ukształtowania relacji pomiędzy wzrostem gospodarczym, dbałością o środowisko (nie tylko przyrodnicze) i jakością życia ${ }^{31}$. Zatem podkreślono niezbędną integrację dzialań w trzech kluczowych obszarach:

1. Wzrostu gospodarczego i równomiernego podziału korzyści. Celem jest osiągnięcie odpowiedzialnego, długookresowego wzrostu, który stanie się udziałem wszystkich narodów i społeczności, ale osiągnięcie go wymaga zintegrowanego podejścia do dzisiejszych, wzajemnie powiązanych globalnych systemów gospodarczych.

2. Ochrony zasobów naturalnych i środowiska. Dla zachowania naszego środowiskowego dziedzictwa i naturalnych zasobów dla przyszłych pokoleń niezbędne jest opracowanie racjonalnych ekonomicznie rozwiązań, które ograniczą zużycie zasobów, powstrzymają skażenie środowiska i ocalą naturalne ekosystemy.

3. Rozwoju społecznego. „Na całym świecie ludzie domagają się pracy, żywności, edukacji, energii, opieki zdrowotnej, wody i systemów sanitarnych. Odpowiadając na te potrzeby, międzynarodowa społeczność musi dołożyć wszelkich starań, by nie zostało naruszone bogactwo kulturowej

\footnotetext{
${ }^{29}$ Nazwa ta pochodzi od nazwiska przewodniczącej komisji Gro Harlem Brundtland.

${ }^{30} \mathrm{http}: / /$ www.agenda21.waw.pl/index.php?option=com_content\&view=article\&id=8\&Itemid=7, (28.02.2014 r.).

${ }^{31} \mathrm{http}: / /$ pl.wikipedia.org/wiki/Zrównoważony_rozwój, (01.03.2014 r.).
} 
i społecznej różnorodności oraz by wszyscy członkowie społeczeństw mieli instrumenty pozwalające na kształtowanie własnej przyszłości”32.

Prace Światowej Komisji ds. Środowiska i Rozwoju ONZ przyczyniły się następnie do zorganizowania „Szczytu Ziemi” w Rio de Janeiro w roku 1992 i przyjęcia na nim programu Agenda 21 stanowiącego ogólnoświatową strategię zrównoważonego rozwoju. Agenda 21 zawiera cztery sekcje, wśród których ujętych jest czterdzieści rozdziałów. Sekcja pierwsza - wymiar społeczny i ekonomiczny - uwzględnia wzajemne zależności między problemami środowiska a ubóstwem, zdrowiem, handlem, zadłużeniem, konsumpcją i demografią. Sekcja druga - konserwacja i gospodarka zasobami - dotyczy sposobów jakimi zasoby naturalne muszą być zarządzane, aby zapewnić zrównoważony rozwój. Sekcja trzecia odnosi się do umacniania roli znaczących grup społecznych w pracy na rzecz zrównoważonego rozwoju. Ostatnia sekcja uwzględnia środki realizacji i rolę różnych rodzajów działalności rządowej i pozarządowej w tym również źródła i sposoby finansowania ${ }^{33}$. Można zatem zauważyć, że spis podstawowych problemów omawianych $\mathrm{w}$ agendzie 21 obejmuje szeroki aspekt znaczenia zrównoważonego rozwoju. W tym wypadku zrównoważenie uwzględnia co najmniej trzy wymiary ekonomiczny, społeczny i środowiskowy. Rysuje się więc nowy obraz równoważenia, gospodarki jak również ekonomii jako nauki. Zdaniem Rogalla ,zrównoważony rozwój zmierza do zapewnienia wszystkim żyjącym dzisiaj ludziom i przyszłym pokoleniom dostatecznie wysokich standardów ekologicznych, ekonomicznych i społeczno-kulturowych w granicach naturalnej wytrzymałości Ziemi, stosując zasadę sprawiedliwości wewnątrzpokoleniowej i międzypokoleniowej”34. Z definicji tej według Rogalla dla ekonomii zrównoważonego rozwoju wynikają cztery zasady:

1) podstawy etyczne,

2) postulat zrównoważonej (społeczno-ekologicznej) demokracji,

3) uznanie bezwzględnych granic naturalnej wytrzymałości,

4) podejście integracyjne. Jednocześnie autor ten wskazuje na trójkąt celów gospodarki zrównoważonego rozwoju, który został zaprezentowany na rys. 7.

32 http://www.unesco.pl/edukacja/dekada-edukacji-nt-zrownowazonego-rozwoju/unesco-azrownowazony-rozwoj, (02.03.2014 r.)

${ }^{33}$ Strukturę Agendy 21 oraz zawartość poszczególny ch sekcji opracowano na podstawie dokumentu: Agenda 21. Przewodnik dla samorzadów, Wydawca Regionalne Samorządowe Centrum Edukacji Ekologicznej przy Sejmiku Samorządowym we Wrocławiu, Wrocław 1993, s. 7 i kolejne, http ://multiversum.org/wp-content/uploads/2014/02/przew_agenda_21.pdf, (02.03.2014r.)

${ }^{34}$ Ibidem, s. 44. 




Rysunek 7. Trójkąt celów gospodarki zrównoważonego rozwoju

Źródło: Opracowanie własne na podstawie: H. Rogall, Ekonomia zrównoważonego rozwoju. Teoria i praktyka, Zysk i S-ka Wydawnictwo, Poznań 2010, s. 47.

Wśród celów ekonomicznych ujętych na rys. 7 wskazać można: stabilność gospodarki narodowej - zapewnienie samodzielnej egzystencji przy akceptowalnej jakości pracy, zaspokojenie podstawowych potrzeb przez zrównoważone produkty (żywność, mieszkania, odzież, energia), stosowne ceny, stabilność cen oraz przeciwdziałanie koncentracji i władzy ekonomicznej, internalizacja kosztów zewnętrznych, pozagospodarcza równowaga i współpraca na rzecz rozwoju przy jak najmniejszym imporcie surowców, wydolny budżet państwowy przy wystarczających standardach zaopatrzenia społeczeństwa w dobra merytoryczne/kolektywne oraz właściwy podział dochodów. Cele ekologiczne obejmują: ochronę atmosfery ziemskiej (ograniczenie ocieplenia klimatu), nieszkodzenie przyrodzie - zachowanie różnorodności gatunkowej i krajobrazowej, zrównoważone wykorzystywanie zasobów odnawialnych, zrównoważone wykorzystywanie zasobów nieodnawialnych, zdrowe warunki życia (eliminowanie szkodliwych substancji, promieniowania i hałasu. $Z$ kolei cele społeczno-kulturowe uwzględniają: demokrację uczestniczącą i praworządność we wszystkich dziedzinach życia, wyeliminowanie ubóstwa, bezpieczeństwo społeczne, opanowanie problemów demograficznych, równość szans, integracja (np. płci, imigran- 
tów), bezpieczeństwo zewnętrzne i wewnętrzne, rozwiązywanie konfliktów bez przemocy, ochrona zdrowia i jakości życia człowieka ${ }^{35}$.

Podsumowując znaczenie równowagi w całym procesie dążeń do zrównoważonego rozwoju można zauważyć, że dominuje równoważenie różnych sfer życia poszczególnych ludzi oraz społeczeństw. Zatem znaczenie równoważenia nabiera wymiaru znacznie szerszego, bowiem zarówno dążenie do równowag cząstkowych jak i równowagi ogólnej sprzyjają dążeniom do realizacji celów gospodarki zrównoważonego rozwoju.

\section{Podsumowanie}

1. Analizując literaturę przedmiotu z zakresu myśli ekonomicznej dotyczącej dociekań na temat równowagi ekonomicznej można przede wszystkim zauważyć, że z biegiem czasu rozważania te ewoluowały oraz stawały się coraz bardziej uporządkowane. Współczesna wiedza o równowadze ekonomicznej stanowi dalece precyzyjny obraz tego stanu poparty złożonymi analizami matematycznymi. Należy jednak podkreślić, że określenie „równowaga ekonomiczna” nie jest jednoznaczne. Pod tą kategorią kryją się zarówno ujęcia równowagi ogólnej, jak również równowagi cząstkowej, uwzględniającej skalę mikroekonomiczną tego stanu, czyli w odniesieniu do rynków konkretnych dóbr i usług, pieniądza, czynników produkcji oraz poszczególnych podmiotów gospodarczych - gospodarstw domowych (konsumentów) i przedsiębiorstw.

2. W teorii ekonomii, ale także w praktyce gospodarczej od wielu lat prezentowane są zróżnicowane poglądy na równowagę ekonomiczną. Zwolennicy równowagi stwierdzają, że w gospodarce najlepiej dzieje się wówczas, gdy występuje równowaga, która zapewnia stabilizację zarówno ekonomiczną, co i ład społeczny. Ze stwierdzenia tego wynikają dwa wnioski:

a) $\mathrm{w}$ gospodarce narodowej należy zapewnić tyle miejsc pracy ile jest chętnych, aby ją podjąć,

b) wielkość produkcji dóbr i usług należy ustalać na podstawie skrupulatnych i wnikliwych analiz społecznych i ekonomicznych.

3. Przeciwnicy równowagi ekonomicznej uważają, że to właśnie nierównowaga jest siłą napędową rozwoju i wzrostu gospodarczego. Wynikają z tego następujące wnioski:

\footnotetext{
${ }^{35}$ H. Rogall, Ekonomia zrównoważonego rozwoju.., op. cit., s. 47.
} 
a) dopiero przewaga popytu nad podażą jest siłą sprawczą gospodarki,

b) niedobór dóbr i usług na rynku mobilizuje zwłaszcza ich wytwórców do poszukiwania nowych dóbr i usług poprzez wynalazki działania innowacyjne, u podstaw których leżą postęp techniczny, technologiczny, organizacyjny i ekonomiczny.

Rezultatem owych przedsięwzięć ma być pojawienie się coraz lepszych jakościowo i niższych kosztowo dóbr i usług.

4. W praktyce gospodarczej wysuwane są postulaty do kręgów kreujących politykę gospodarczą, które można sprowadzić do następujących:

a) gremia ustawodawcze państwa (parlament, sejm, senat) i wykonawcze (rząd, ministerstwa) muszą z jednej strony tworzyć dobre prawo gospodarcze (ustawy sejmowe, uchwały rządowe, zarządzenia resortowe), które powinny być stanowione w sposób jasny i przejrzysty, obowiązywać bez konieczności zmian przez dłuższy okres,

b) to na władzach państwowych i samorządowych wszelkich szczebli ciąży odpowiedzialność za kreowanie gospodarki poprzez zrównoważony rozwój wewnętrzny (gospodarka danego państwa) i rozwój zewnętrzny (w ramach Unii Europejskiej,...),

c) rząd odpowiedzialny jest $\mathrm{z}$ jednej strony za redystrybucję produktu narodowego, $\mathrm{z}$ drugiej natomiast za sprawne i konsekwentne spetnianie funkcji kontrolnej odnoszącej się do wszystkich ogniw administracji państwowej oraz organizacji i podmiotów gospodarczych poprzez narzędzia i instytucje kontrolne.

5. Teoretyczne dywagacje odnoszące się do akceptacji równowagi ekonomicznej prowadzą często do stagnacji i marazmu w rozwoju i wzroście gospodarczym. Doświadczenia płynące od aktywnej praktyki gospodarczej wskazują dobitnie, że to właśnie nierównowaga jest siłą napędzającą rozwój i wzrost gospodarczy, poprzez wykorzystywanie efektów postępu technicznego, organizacyjnego i ekonomicznego. Wypływa stąd przeświadczenie, że istotniejszą wagę należy przywiązywać do płaszczyzn nierównowagi (nadwyżki lub niedoboru podaży i popytu) na otwartym rynku dóbr i usług, a nie do punktu równowagi ekonomicznej i dążeniu wszelkimi środkami do jego uzyskania.

6. Mimo rozbieżności między teorią i praktyką w odniesieniu do stanu równowagi, przy dążeniach międzynarodowych do realizacji idei zrównoważonego rozwoju należy podkreślić, że jest to stan, przynajmniej w rozu- 
mieniu równowagi ogólnej, szczególnie wskazany i pożądany, jako ten, który tę ideę warunkuje.

\section{Bibliografia}

Agenda 21. Przewodnik dla samorządów, Wydawca Regionalne Samorządowe Centrum Edukacji Ekologicznej przy Sejmiku Samorządowym we Wrocławiu, Wrocław 1993.

Bartkowiak R., Historia myśli ekonomicznej. Polskie Wydawnictwo Ekonomiczne, Warszawa 2003.

Blaug M., Teoria ekonomii. Ujęcie retrospektywne. Wydawnictwo Naukowe PWN, Warszawa 2000.

Górski J., Sierpiński W., Historia powszechnej myśli ekonomicznej (1870-1950). Państwowe Wydawnictwo Naukowe, Warszawa 1987.

http://multiversum.org/wp-content/uploads/2014/02/przew_agenda_21.pdf, (02.03.2014r.)

http://pl.wikipedia.org/wiki/Zrównoważony_rozwój, (01.03.2014r.).

$\mathrm{http}: / /$ www.agenda21.waw.pl/index.php?option=com_content\&view=article\&id=8\&Item $\mathrm{id}=7,(28.02 .2014 \mathrm{r}$.).

http://www.unesco.pl/edukacja/dekada-edukacji-nt-zrownowazonego-rozwoju/unesco-azrownowazony-rozwoj, (02.03.2014r.)

Keynes J. M., Ogólna teoria zatrudnienia, procentu i pieniq̨dza. Wydawnictwo Naukowe. PWN, Warszawa 2003.

Kornai J., Anti-Equilibrium. Teoria systemów gospodarczych. Kierunki badań. PWN, Warszawa 1975.

Landreth H., Colander D.C., Historia myśli ekonomicznej. Wydawnictwo Naukowe PWN, 2005.

Rogall H., Ekonomia zrównoważonego rozwoju. Teoria i praktyka. Zysk i S-ka Wydawnictwo, Poznań 2010.

Stownik historii myśli ekonomicznej. red. E. Kundera, Oficyna Ekonomiczna, Kraków 2004.

Stownik języka polskiego. PWN, Warszawa 1979, t. II. s. 908 i t. III s. 494,

Stownik wyrazów obcych. PWN, Warszawa 1995.

Stankiewicz W., Historia myśli ekonomicznej. Polskie Wydawnictwo Ekonomiczne, Warszawa 2007.

Witte H., Die nachhaltige Marktwirtschaft. Wohlstand ohne self-made Krisen? LIT VERLAG, Berlin 2013. 


\section{Theoretical economic equilibrium} and practical economic dis equilibrium

\section{Summary}

The economic equilibrium is not an unequivocal term. Depending on criteria used it can be analyzed in different ways. However, historically, inquiries about the market equilibrium has evolved and helped to sort out related matters. Today we can say that the economic equilibrium often treated as a theoretical model-based composition with a number of assumptions and simplifications is a state difficult to achieve and maintain. It is a kind of a trend shaped by a series of often unpredictable factors. The practice indicates the economic importance of imbalance as the driving force of growth and socioeconomic development. 